\title{
Spawning, embryo development and growth of the American sand lance Ammodytes americanus in the laboratory
}

\author{
Alphonse S. Smigielski, Thomas A. Halavik, Lawrence J. Buckley, Shawn M. Drew \\ and Geoffrey C. Laurence
}

National Oceanic and Atmospheric Administration, National Marine Fisheries Service, Northeast Fisheries Center, Narragansett Laboratory, Narragansett, Rhode Island 028821199 , USA*

\begin{abstract}
Ammodytes americanus adults were captured and transported to the laboratory and spawned. Eggs and larvae were successfully incubated at $2,4,7$ and $10^{\circ} \mathrm{C}$. Specific growth rates in dry wt per day were $2.4 \%$ at $2{ }^{\circ} \mathrm{C}, 3.23 \%$ at $4{ }^{\circ} \mathrm{C}, 4.75 \%$ at $7{ }^{\circ} \mathrm{C}$ and $5.62 \%$ at $10^{\circ} \mathrm{C}$. This was the first successful attempt to spawn sand lance in the laboratory and to rear the larvae through metamorphosis. The early life history of this fish can be completed under controlled laboratory conditions.
\end{abstract}

\section{INTRODUCTION}

The American sand lance Ammodytes americanus occurs along the Atlantic coast of North America from Cape Hatteras to the Gulf of St. Lawrence, northern Newfoundland, and northern Labrador to Hudson Bay. Its European relative, A. tobianus, occurs from Greenland, Iceland, northern Scandinavia and the White Sea south to Spain (Bigelow and Schroeder, 1953).

Two species of sand lance are recognized as living on the east coast of North America: Ammodytes americanus, an inshore species, and A. dubius, an offshore species. Their taxonomy remains confused; until the relationship of these species is clarified, we are following Leim and Scott (1966) and Reay (1970) in the use of $A$. americanus for the inshore species of sand lance.

The sand lance plays a very important role in the economy of northern seas preying on secondary producers and constituting an important food of higher trophic level fish and mammals. Interest in sand lance has increased as their level of abundance has shifted in both the Northwest Atlantic ecosystem off the northeastern United States and in the North Sea (Sherman et al, 1981).

\footnotetext{
- Reference to trade names does not imply endorsement by
} the National Marine Fisheries Service, NOAA.
Sand lance spawn from Canada to Virginia. Spawning from the Gulf of Maine to Cape Hatteras is widespread over the continental shelf (Richards and Kendall, 1973; Sherman et al., 1982). Although sand lance have never been observed spawning naturally, it is believed that in the Merrimack River Estuary of Massachusetts they spawn in early December when water temperatures are 4.4 to $6.3^{\circ} \mathrm{C}$ (Peterson, 1975). The eggs of Ammodytes americanus have been partially described (Williams et al., 1964) but actual incubating times, embryonic development and hatch durations under controlled conditions prior to this study were not available.

Since the sand lance has become such a significant biomass component of the ecosystem on the Atlantic coast of North America, it was necessary to conduct laboratory research to determine important and unknown early life-history parameters (i.e. egg development rates, growth rates) relevant to population dynamics and ecosystem structure as part of the Northeast Fisheries Center's continuing MARMAP studies.

\section{MATERIALS AND METHODS}

Adult Ammodytes americanus were captured in the Merrimack River Estuary in November 1981 (Jerome et al., 1965). Several hundred were transported live to the 
Narragansett laboratory in a 380-1 live car equipped with an aerator. The fish were held in two circular 900I fiberglass tanks. A continual supply of seawater was pumped into the tanks from Narragansett Bay.

While the fish were held in captivity, a photoperiod $10 \mathrm{~h}$ of light and $14 \mathrm{~h}$ of dark (10L:14D) simulated spawning light conditions. Four banks of fluorescent lights (each bank composed of sixteen $40-\mathrm{W}$ bulbs) were suspended $4 \mathrm{~m}$ above the tanks and mechanically timed. The light banks were sequentially turned on and off in the morning and evening at 15-min intervals to simulate dawn and twilight.

The sand lance were allowed to acclimate for a period of $2 \mathrm{wk}$ before any handling was attempted. After acclimating the sand lance were examined weekly for spawning readiness. Injured or moribund specimens were removed and gonadosomatic indices (GSI) recorded. The gonosomatic index expresses wet gonad weight as a percentage of total body weight (gonad weight/body weight $\times 100$ ). To minimize injuries they were anesthetized in a solution of tricane methanesulfonate (MS 222) at a concentration of $1: 20,000$ (Leitritz and Lewis, 1976) during each examination.

While held in captivity, the sand lance were fed cultured nauplii of Artemia sp. and wild plankton obtained from Narragansett Bay. Approximately $20 \%$ of the fish appeared to feed during the time they were held in the laboratory. It is not known if they fast prior to spawning or if the stresses associated with captivity played a role in their apparent lack of appetite.

The water temperature in the holding tanks was initially at the ambient bay temperature of $11^{\circ} \mathrm{C}$ and declined to $7^{\circ} \mathrm{C}$ in $5 \mathrm{wk}$. The first spawning occurred at $7^{\circ} \mathrm{C}$ and terminated $17 \mathrm{~d}$ later when the temperature dropped to $4.5^{\circ} \mathrm{C}$.

Running ripe fish were stripped by hand and a ratio of $3: 1$ males to females was adhered to whenever possible. Sand lance spawn adhesive demersal eggs which form clumps under experimental conditions. Spawned and fertilized eggs were handled and prevented from clumping using diatomaceous earth according to the techniques of Smigielski and Arnold (1972). Some fish were spawned directly into nitex baskets without separating for comparison against treated eggs.

Fertilized eggs both treated and untreated were held in $425 \mu \mathrm{m}$ nitex baskets $(42 \mathrm{~cm} \times 20 \mathrm{~cm} \times 16 \mathrm{~cm})$ and suspended in static $30-1$ aquaria to incubate. The aquaria contained filtered seawater at $30 \% \mathrm{~S}$ and were aerated with a single air stone. A single application of penicillin (25 international units [IU] $\mathrm{ml}^{-1}$ ) and streptomycin $\left(0.02 \mathrm{mg} \mathrm{ml}^{-1}\right)$ at the concentration of 50 mg $1^{-1}$ (Smigielski, 1979) was effective in controlling bacterial contamination of the aquaria. The aquaria were held in water baths equipped with programmable controls that balanced cooling and heating coils and maintained the desired incubating temperatures (Fig. 1).

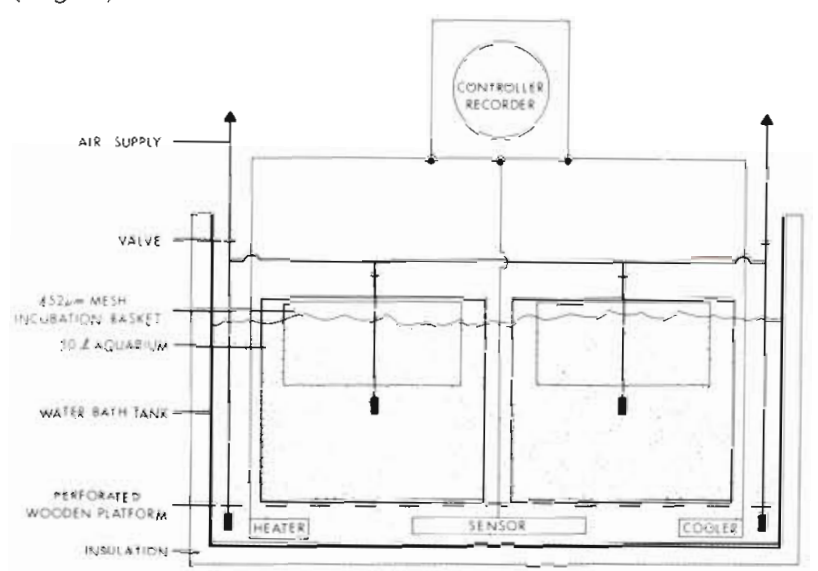

Fig. 1. Ammodytes americanus. Constant temperature apparatus used for incubating and growth studies

Groups of fertilized eggs were incubated at 2, 4, 7 and $10^{\circ} \mathrm{C}$ after being tempered to the desired incubating temperatures at the rate of $1 \mathrm{C}^{\circ}$ every $6 \mathrm{~h}$. Developing embryos were removed from the $7^{\circ} \mathrm{C}$ group and photographed daily until hatching.

The staging of developing embryos in this research at $7^{\circ} \mathrm{C}$ (Fig. 2) is as follows:

Stage I: ( 0 to 2 d) from fertilization to formation of complete blastodermal cap.

Stage II: ( 2 to 6 d) from formation of completed blastodermal cap through development of segmentation cavity to first appearance of germinal ring and embryonic axis.

Stage III: (6 to 12 d) early embryo, from appearance of germinal ring and embryonic axis to closure of blastophore. At closing of the blastophore eyes of the embryo become differentiated. Tail bud becomes separated from yolk.

Stage IV: (12 to 22 d) middle stage embryo, developing embryo encircles yolk, somites visible, head well defined, optic vesicles prominent.

Stage V: (23 to $30 \mathrm{~d}$ ) advanced stage embryo, tail twists out of embryonic axis, myomeres visible along most of embryo, eyes pigmented.

Stage VI: (30 to 39 d) late stage embryo, embryo has grown so large that its tail twists around yolk several times, myomeres visible except near end of tail, embryo very active, exhibiting convulsive movements at frequent intervals until hatching.

Upon hatching, larvae were utilized in feeding (Buckley et al., 1982) and growth studies at the test temperatures of $2,4,7$ and $10^{\circ} \mathrm{C}$. Rearing aquaria were initially inoculated with the dinoflagellate Tetraselmis soucii. The larvae did not feed intensively on the 

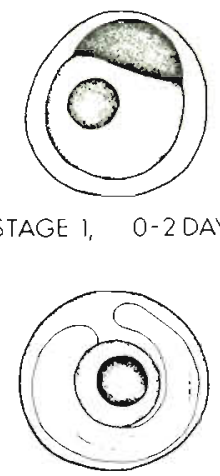

STAGE 3, 6-12 DAYS

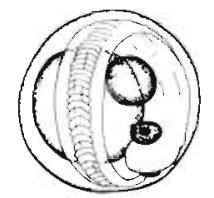

STAGE 5, 22-30 DAYS
STAGE I, 0-2 DAYS

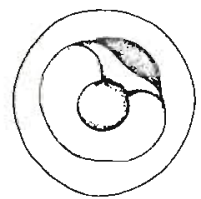

STAGE 2, 2-6DAYS

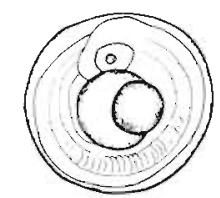

STAGE $4,12-22$ DAYS

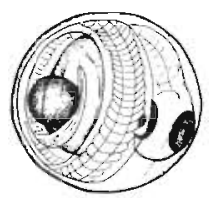

STAGE 6, 30-39DAYS
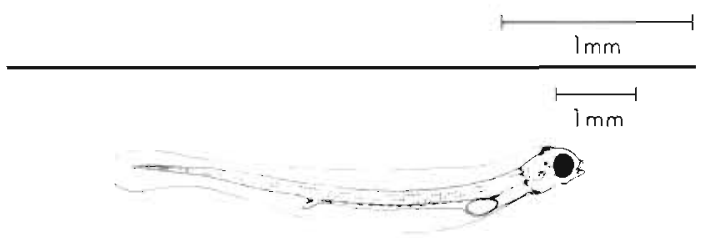

NEWLY HATCHED LARVAE

Fig. 2. Ammodytes americanus. Staging classification for embryos from fertilization to hatching

phytoplankton; its value was probably more important as a conditioner of the rearing systems and as a food source for the zooplankton that was fed to the larvae. Harada (1970) reported that Japanese fish culturists usually incorporate blooms of algae to remove the metabolic wastes of larvae and to supply oxygen.

First feeding larvae were fed 'ad libitum' cultured rotifers Brachionus plicatilis $(>100 \mu \mathrm{m}$ in largest dimensions) for several weeks. This was followed by wild copepod nauplii and aduits consisting primarily of Acartia sp., Eurytemora sp. and Cladocera (Podon sp.) from a nearby estuary. They were sieved through a $210-\mu \mathrm{m}$ mesh strainer and as the larvae increased in size cultured brine shrimp nauplii ( 450 to $500 \mu \mathrm{m}$ ) were fed.

Five banks of timed fluorescent lights (each bank composed of two 40-W bulbs) suspended $1 \mathrm{~m}$ over the aquaria simulated seasonal day and night regimen of $11 \mathrm{~h}$ light and $13 \mathrm{~h}$ dark (11L: 13D) during the rearing period.

Samples of larvae for individual standard lengths and dry weights were taken on a daily basis until $50 \%$ had initiated feeding and then on a weekly basis. Samples consisted of 10 larvae from each test temperature. Standard lengths were measured to the nearest $0.1 \mathrm{~mm}$ with a filar micrometer in a dissecting microscope. Dry weight was determined by rinsing larvae in distilled water, pipetting on a glass Petri dish, freeze drying and weighing individually to the nearest $0.1 \mu \mathrm{g}$ on a Cahn automatic electrobalance.

Daily growth rates were calculated from the slopes of the regression equations describing the relations between age in days and standard length in mm or the $\log _{10}$ of dry weight in mg. Daily growth rates were multiplied by 31 to determine the increase in length per month.

\section{RESULTS AND DISCUSSION}

Gonadosomatic indices (GSI) of captive fish of both sexes were recorded in November and December (Table 1). Gonads of females were slightly further developed in December while in males they remained virtually unchanged. Some males were running ripe in late November but the majority had ripened by the middle of December which coincided with the females' spawning

The weights of fishes immediately before and after spawning were recorded and a mean weight loss greater than $35 \%$ was observed. Scott (1972b) noted losses of about $30 \%$ for Ammodytes dubius while

Table 1. Ammodytes americanus. Gonadosomatic indices, November-December 1981

\begin{tabular}{|c|c|c|c|c|c|}
\hline Date & $N$ & Sex & $\mathrm{FL}(\mathrm{mm})$ & Wt $(\mathrm{g})$ & GSI \\
\hline \multirow[t]{2}{*}{$\begin{array}{l}\text { November } \\
\bar{X} \text { Water temp. } 9.4^{\circ} \mathrm{C}\end{array}$} & 19 & Male & $\begin{aligned} \bar{X} & =148.21 \\
\text { S.D. } & =16.95\end{aligned}$ & $\begin{array}{r}\bar{X}=11.48 \\
\text { S.D. }=3.93\end{array}$ & $\begin{array}{r}\bar{X}=25.71 \\
\text { S.D. }=3.69\end{array}$ \\
\hline & 12 & Female & $\begin{array}{r}\bar{X}=147.58 \\
\text { S.D. }=25.30\end{array}$ & $\begin{array}{r}\bar{X}=11.50 \\
\text { S.D. }=4.44\end{array}$ & $\begin{array}{r}\bar{X}=26.71 \\
\text { S.D. }=3.99\end{array}$ \\
\hline \multirow[t]{2}{*}{$\begin{array}{l}\text { December } \\
\text { X Water temp. } 6.6^{\circ} \mathrm{C}\end{array}$} & 44 & Male & $\begin{array}{r}\bar{X}=144.66 \\
\text { S.D. }=23.05\end{array}$ & $\begin{array}{r}\bar{X}=10.63 \\
\text { S.D. }=4.79\end{array}$ & $\begin{array}{r}\bar{X}=25.62 \\
\text { S.D. }=4.81\end{array}$ \\
\hline & 27 & Female & $\begin{array}{r}\bar{X}=148.85 \\
\text { S.D. }=18.59\end{array}$ & $\begin{array}{r}\bar{X}=10.99 \\
\text { S.D. }=3.76\end{array}$ & $\begin{array}{r}\bar{X}=28.64 \\
\text { S.D. }=5.46\end{array}$ \\
\hline
\end{tabular}


Westin et al. (1979) indicated that females of $A$. americanus from the Merrimack River and Block Island Sound lost up to $45 \%$ of their body weight during the spawning season.

It is not known if Ammodytes are synchronous or nonsynchronous spawners in the natural environment; however, fish autopsied after spawning in the laboratory had very few eggs remaining in their ovaries. The small size and delicate nature of Ammodytes presented some problems in stripping. Excessive pressure ruptured membranes holding the eggs, injured the ovaries and resulted in lowered egg survival. Gentle pressure applied along the abdomen anterior to the vent with the thumb was sufficient to assist the natural flow of the eggs. This process was continued until all the eggs that came freely were obtained.

Egg diameters ranged from 0.94 to $1.03 \mathrm{~mm}(\overline{\mathrm{X}}=$ $1.00 \mathrm{~mm}$ ) and contained one oil globule 0.28 to $0.38 \mathrm{~mm}(\overline{\mathrm{X}}=0.35 \mathrm{~mm})$. Williams et al. (1964) collected Ammodytes eggs in the locality of Long Island, New York, and reported their diameters as ranging from 0.67 to $0.91 \mathrm{~mm}$ ( $\overline{\mathrm{X}}=0.83 \mathrm{~mm}$ ) and the oil globule 0.17 to $0.33 \mathrm{~mm}(\overline{\mathrm{X}}=0.22 \mathrm{~mm})$.

Fertilization and hatching percentages for eggs treated with diatomaceous earth at all incubating temperatures were very good $(>90 \%)$, the untreated eggs displayed similar high fertilization rates at all temperatures but their hatch rates were Iower $(\sim 75 \%)$. It was observed that clumping caused the eggs, which were several layers thick, to smother after developing to Stage II.

Times from fertilization to the beginning of hatching, from initiation of hatch to $50 \%$ hatch and hatch duration were 61,21 , and $74 \mathrm{~d}$, respectively, at $2^{\circ} \mathrm{C}$, additional times for 4,7 and $10^{\circ} \mathrm{C}$ are listed in Table 2 . Incubation and hatch duration for Ammodytes americanus was unusually long, confirming observations reported by Covill (1959). The long incubating times for sand lance observed in the laboratory may be an artifact of the tranquil conditions that prevailed for the eggs. A. americanus eggs have never been
Table 2. Ammodytes americanus. Hatch and developmental times in days

\begin{tabular}{|c|c|c|c|c|}
\hline Time interval & $2^{\circ} \mathrm{C}$ & $4^{\circ} \mathrm{C}$ & $7^{\circ} \mathrm{C}$ & $10^{\circ} \mathrm{C}$ \\
\hline $\begin{array}{l}\text { Spawning to beginning } \\
\text { of hatch }\end{array}$ & 61 & 51 & 39 & 25 \\
\hline $50 \%$ hatch & 21 & 16 & 9 & 5 \\
\hline Hatch duration & 74 & 65 & 43 & 30 \\
\hline $\begin{array}{l}\text { Total time to } \\
\text { hatch completion }\end{array}$ & 135 & 116 & 82 & 55 \\
\hline Yolk sac absorption & 7 & 5 & 3 & 2 \\
\hline Oil globule absorption & 14 & 12 & 7 & 5 \\
\hline $\begin{array}{l}\text { First feeding larvae } \\
\text { (50\% feeding) }\end{array}$ & 2 & 1 & 2 & 1 \\
\hline
\end{tabular}

observed incubating in the natural environment. Any role of mechanical action due to tidal forces in accelerating hatching is speculative.

The mean standard lengths at hatching at 2, 4, 7 and $10^{\circ} \mathrm{C}$ were $6.24,6.34,5.71$ and $6.06 \mathrm{~mm}$. These lengths were greater than those reported for Ammodytessp. by Scott (1972a) and assumed by Morse (1982) but similar to those reported for larvae collected along the west coast of Greenland by Richards (1965).

Ammodytes americanus are fully developed at hatching possessing pigmented eyes, a complete gut and functional mouth. The times from hatching to completion of yolk sac absorption, oil globule absorption and first feeding were noted (Table 2). At all test temperatures there were individuals that commenced feeding several hours after hatching. Yolk sac absorption occurred when larvae were between 6.3 and $6.8 \mathrm{~mm}$ long and oil globule absorption when larvae were 7.2 and $7.4 \mathrm{~mm}$ in length (Table 3).

The first fish metamorphosed $131 \mathrm{~d}$ after hatching at $4{ }^{\circ} \mathrm{C}$ and $102 \mathrm{~d}$ at $7^{\circ} \mathrm{C}$ when they achieved a length of $29 \mathrm{~mm}$. Reay (1970) suggested a larval phase duration for wintering-over larvae in the order of 3 to 5 mo and completion to metamorphosis (Macer, 1965) between 30 and $40 \mathrm{~mm}$. At the termination of the study fish held

Table 3. Ammodytes americanus. Standard lengths at various stages of development

\begin{tabular}{|c|c|c|c|c|}
\hline Stage & $2^{\circ} \mathrm{C}$ & $4^{\circ} \mathrm{C}$ & $7^{\circ} \mathrm{C}$ & $10^{\circ} \mathrm{C}$ \\
\hline $\begin{array}{l}\text { Yolk sac }{ }^{1} \\
\text { absorption }\end{array}$ & $\begin{aligned} \bar{X} & =6.77 \\
\text { S.D. } & =.434\end{aligned}$ & $\begin{aligned} \bar{X} & =6.69 \\
\text { S.D. } & =.323\end{aligned}$ & $\begin{aligned} \bar{X} & =6.45 \\
\text { S.D. } & =.223\end{aligned}$ & $\begin{aligned} \overline{\mathrm{X}} & =6.26 \\
\text { S.D. } & =.305\end{aligned}$ \\
\hline $\begin{array}{l}\text { Oil globule } \\
\text { absorption }\end{array}$ & $\begin{aligned} \overline{\mathrm{X}} & =7.22 \\
\text { S.D. } & =.725\end{aligned}$ & $\begin{aligned} \bar{X} & =7.37 \\
\text { S.D. } & =.970\end{aligned}$ & $\begin{aligned} \bar{X} & =7.20 \\
\text { S.D. } & =309\end{aligned}$ & $\begin{aligned} \bar{X} & =7.41 \\
\text { S.D. } & =.743\end{aligned}$ \\
\hline $\begin{array}{l}\text { First feeding } \\
\text { larvae }(50 \%)\end{array}$ & $\begin{aligned} \bar{X} & =6.51 \\
\text { S.D. } & =.171\end{aligned}$ & $\begin{aligned} \overline{\mathrm{X}} & =6.22 \\
\text { S.D. } & =.419\end{aligned}$ & $\begin{aligned} \bar{X} & =6.45 \\
\text { S.D. } & =.223\end{aligned}$ & $\begin{aligned} \bar{X} & =6.43 \\
\text { S.D. } & =.423\end{aligned}$ \\
\hline
\end{tabular}


at $2{ }^{\circ} \mathrm{C}$ for $149 \mathrm{~d}$ had not metamorphosed and due to a malfunction, measurements on the fish held at $10^{\circ} \mathrm{C}$ were terminated after $61 \mathrm{~d}$.

A group of fish reared at $7^{\circ} \mathrm{C}$ in a 600 -1 fiberglass tank with a sand bottom $(10 \mathrm{~cm}$ deep) exhibited schooling behavior $90 \mathrm{~d}$ after hatching after attaining lengths of 25 to $30 \mathrm{~mm}$. They were also observed burrowing into the bottom $133 \mathrm{~d}$ after hatching when they were between 35 and $40 \mathrm{~mm}$ in length. The fish would remain buried for several days (Scott, 1973) only to emerge in groups of 2 and 3, or several dozen, and begin actively seeking food on the surface.

Ammodytes americanus were fed ad libitum more than 2 plankters $\mathrm{ml}^{-1}$ daily from the onset of hatching and throughout the entire study time. Growth of larval A. americanus was influenced by temperature (Fig. 3).

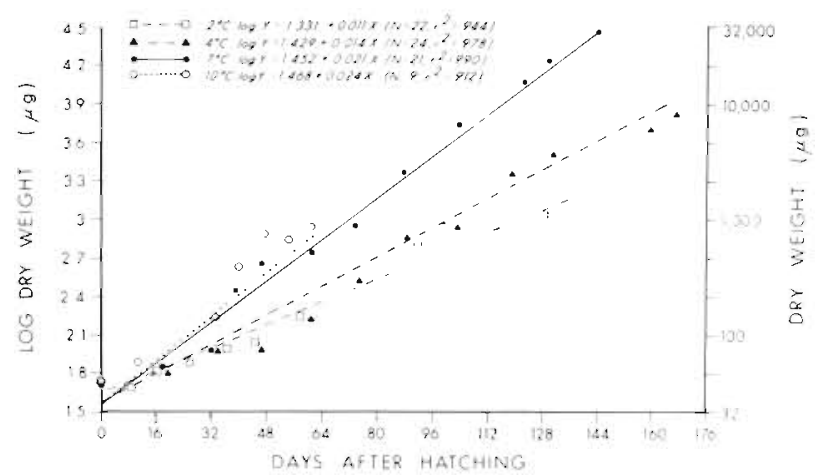

Fig. 3. Ammodytes americanus. Regression equations and average weekly dry weights at 4 temperatures during laboratory studies

Specific growth rates in dry weight per day were $2.4 \%$ at $2{ }^{\circ} \mathrm{C}, 3.23 \%$ at $4{ }^{\circ} \mathrm{C}, 4.75 \%$ at $7{ }^{\circ} \mathrm{C}$ and $5.62 \%$ at $10^{\circ} \mathrm{C}$. Buckley (unpubl.) examined sand lance collected on Georges Bank between 2 and $6{ }^{\circ} \mathrm{C}$, and estimated their short-term protein growth rates from RNA-DNA ratio measurements and temperature. Growth rates ranged from 9.9 to $23.9 \% \mathrm{~d}^{-1}$ in 1981 and from 4.9 to $13.1 \% \mathrm{~d}^{-1}$ in 1982 .

Changes in length frequency distributions of Ammodytes sp. captured in the field have been used to estimate growth rates. Growth estimates have also been obtained by reading otoliths with well defined annuli (Scott, 1968). Estimated increases per month for Ammodytes sp. reported are $11.6 \mathrm{~mm}$ (Norcross et al., 1961), $6.75 \mathrm{~mm}$ (Pelligrini, 1976), $5.9 \mathrm{~mm}$ (Scott, 1972b), and 3 to $5 \mathrm{~mm}$ (Wheatland, 1956). $A$. americanus reared in the laboratory had attained growth rates of $0.73,0.88,1.22$ and $1.53 \%$ increase in standard length per day (Fig. 4) at 2, 4, 7 and $10^{\circ} \mathrm{C}$. These rates correspond to $2.73,3.58,6.92$ and $11.31 \mathrm{~mm} \mathrm{mo}^{-1}$ for $155 \mathrm{~d}$ of growth.

Large differences in the dry weight of individuals were noted in all experimental groups throughout the

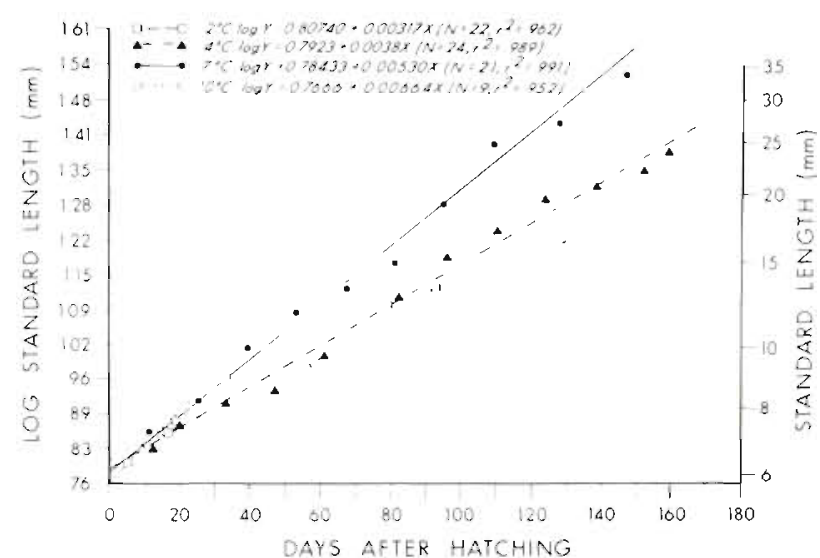

Fig. 4. Ammodytes americanus. Weekly mean standard lengths and regression relationships at 4 temperatures during laboratory studies

study. Among individuals, extremes of 300 to $700 \%$ were measured. This uneven size may be attributed to the fact that newly hatched larvae were entering the population daily for several weeks. As hatch duration times were quite lengthy, many of the larvae were established feeders for a considerable period of time before their newly hatched cohorts entered the population. Prolonged hatching may also have resulted in an underestimation of growth rate in the present study. It is not known for certain if hatch duration is as long in the natural environment, but observations by Wheatland (1956), Covill (1959), and Richards and Kendall (1973) suggest a lengthy hatching period.

Ammodytes sp. are apparently very opportunistic and will quickly fill a niche if larger predators are removed from the ecosystem (Sherman et al., 1981). The result of this study, reporting in part on their high fecundity is in agreement with the high biomass estimates of Morse (1982). The extremely long hatch duration and ability to survive and grow at low water temperatures ( 2 to $4{ }^{\circ} \mathrm{C}$ ) for a considerable period of time suggests that these fish have adapted well to survival in the less than optimal conditons of late winter when the density of zooplankton prey is at the annual minimum throughout their spawning range of the northeastern coast of the United States.

Acknowledgements. We would like to thank L. Armstrong for the line drawings of the embryonic development of the sand lance and for drafting the figures. Thanks also go to B. Burns for establishing and maintaining the algae and rotifer cultures and to C. A. Smigielski for providing statistical assistance. This is MARMAP Contribution No. MED/NEFC 82-63.

\section{LITERATURE CITED}

Bigelow, H. B., Schroeder, W. C. (1953). Fishes of the Gulf of Maine. Fish. Bull. Fish Wild. Serv. U. S. 53: 1-577

Buckley, L. J., Turner, S. J., Halavik, T. A., Smigielski, A. S., 
Drew, S. M., Laurence, G. C. (1983). Effects of temperature and food availability on growth, survival, and RNA-DNA ratio of sand lance (Ammodytes americanus) larvae (in prep.)

Covill, R. W. (1959). Food and feeding habits of larvae and postlarvae of Ammodytes americanus, 1952-1955. Bull Bingham oceanogr Coll. 17: 125-146.

Harada, T. (1970). The present status of marine fish cultivation research in Japan. Helgoländer wiss. Meeresunters. 20: 594-601

Jerome, W. C., Chesmore, A. P., Anderson, C. O., Jr., Rice, F. G. (1965). A study of the marine resources of the Merrimack River Estuary. Mass. Div. Marine Fisheries, Mono. Ser. 6: 1-79

Leim, A. H., Scott, W. B. (1966). Fishes of the Atlantic coast of Canada. Bull. Fish. Res. Bd Can. 155: 1-485

Leitritz, E., Lewis, R. C. (1976). Trout and salmon culture (hatchery methods), Calif. Fish Game Fish. Bull. 164: $1-197$

Macer, C. T. (1965). The distribution of larval sand lance (Ammodytidae) in the southern North Sea. J. mar. biol. Ass. U. K. 45: 187-207

Morse, W. (1982). Spawning stock biomass estimates of sand lance, Ammodytes sp., off northeastern United States, determined from MARMAP plankton surveys, 1974-1980. International Council for the Exploration of the Seas, C. M. 1982/G: 59 (mimeographed)

Norcross, J. J., Massman, W. H., Joseph, E. R. (1961). Investigations of inner continental shelf waters off lower Chesapeake Bay. Part II. Sand lance, Ammodytes americanus. Chesapeake Sci. 2: 49-59

Pellegrini, R. H. (1976). Aspects of the biology of the American sand lance, Ammodytes americanus, from the lower Merrimack River Estuary, Massachusetts. MS thesis, University of New Hampshire

Peterson, S. J. (1975). The seasonal abundance and distribution of fish eggs, larvae and juveniles in the Merrimack River Estuary, Massachusetts, 1974-1975. M. Sc. thesis, University of Massachusetts-Amherst

Reay, P. S. (1970). Synopsis of biological data on North Atlantic sand eels of the genus Ammodytes, A. tobianus, A. dubius, A. americanus, A. marinus. F. A. O. Fish. Synopses 82: $1-52$

Richards, S. W. (1965). Description of the postlarvae of the sand lance (Ammodytes) from the east coast of North America. J. Fish. Res. Bd Can. 22: 1313-1317

Richards, S. W., Kendall, A. W (1973). Distribution of sand lance, Ammodytes sp., larvae on the continental shelf from Cape Cod to Cape Hatteras from R/V Dolphin surveys in 1966. Fish. Bull. U. S. 71: 371-386

Scott, J. S. (1968). Morphometrics, distribution, growth and maturity of offshore sand lance (Ammodytes dubius) on the Nova Scotia banks. J. Fish. Res. Bd Can. 25 (9): $1775-1785$

Scott, J. S. (1972a). Eggs and larvae of northern sand lance (Ammodytes dubius) from the Scotian Shelf. J. Fish. Res. Bd Can. 29: 1667-1671

Scott, J. S. (1972b). Morphological and meristic variations in northwest sand lances (Ammodytes). J. Fish. Res. Bd Can. 29: $1673-1678$

Scott, J. S. (1973). Food and inferred feeding behavior of northern sand lance (Ammodytes dubius). J. Fish. Res. Bd Can. 30: 451-454

Sherman, K., Jones, C., Sullivan, L., Smith, W., Berrien, P., Ejsymont, L. (1981). Congruent shifts in sand eel abundance in western and eastern North Atlantic ecosystems. Nature, Lond. 291 (5815): 486-489

Smigielski, A. S. (1979). Induced spawning and larval rearing of the yellowtail flounder, Limanda ferruginea. Fish. Bull. U. S. 76: 931-936

Smigielski, A. S., Arnold, C. R. (1972). Separating and incubating winter flounder eggs. Progve Fish Cult. 34: 113

Westin, D. T., Abernethy, K. J., Meller, L. E., Rogers, B. A. (1979). Some aspects of biology of the American sand lance, Ammodytes americanus. Trans. Am. Fish. Soc. 108 328-331

Wheatland, S. B. (1956). Oceanography of Long Island Sound, 1952-54. VII. Pelagic fish eggs and larvae. Bull. Bingham oceanogr. Coll. 15: 734-814

Williams, G. C., Richards, S. W., Farnworth, E. G. (1964). Eggs of Ammodytes hexapterus from Long Island, New York. Copeia 1964: 242-243 